\title{
Effect of Drinking Water Having High F Level on Livestock Health in Mansa and Bathinda Districts of Punjab, India
}

\author{
Shikha Raina", Kirti Dua and Sikhtejinder Singh \\ Department of Veterinary Medicine, Guru Angad Dev Veterinary and Animal Sciences \\ University, Ludhiana, India \\ *Corresponding author
}

\section{A B S T R A C T}

\section{Keywords}

Fluoride, Hydrofluorosis, Dental mottling, Lameness, Livestock

Article Info

Accepted: xx July 2019 Available Online: xx August 2019
Excessive intake of fluoride, mainly through drinking water is a serious health hazard affecting humans as well as livestock worldwide. According to previous researches, the South-western region of Punjab is endemic for hydrofluoroisis and the fluoride concentrations beyond the standard level results in dental and skeletal fluorosis. This paper highlights the highest fluoride concentration in drinking water of Mansa and Bathinda districts of Punjab which comes under the South-Western region of Punjab. A total of 220 water samples from 7 villages of Mansa and 3 villages of Bathinda were collected and analysed for $\mathrm{F}$ level. It was found that $44.6 \%$ water samples from Mansa and $36.2 \%$ water samples from Bathinda were having $\mathrm{F}$ level above permissible limit (i.e. $>1.5 \mathrm{ppm}$ ). The highest $\mathrm{F}$ level in the drinking water found in Ghele $(6.21 \pm 0.64)$ and Gheri $(4.1 \pm 0.45)$ village of Mansa and Bathinda district respectively. The clinical manifestations observed in the livestock were dental mottling and lameness in such areas. In village Ghele of district Mansa $25.6 \%$ of the dairy animals manifest dental mottling whereas $51.6 \%$ of animals showed skeletal fluorosis. Similarly, in Gheri village of district Bathinda, maximum cases of dental mottling $(52.6 \%)$ and lameness $(39.8 \%)$ was found in livestock. Besides that, the significant positive correlation of $\mathrm{F}$ was observed with water $\mathrm{pH}$ and alkalinity was observed.

\section{Introduction}

Water is frequently referred as a universal solvent, because of its ability to dissolve almost all substances that comes in its contact. Some elements are essential in trace amount for human being as well as animals while higher concentration of the same can cause toxic effects. Fluoride is one of them which is $13^{\text {th }}$ prevalent naturally occurring element in earth's crust. Since it is most electronegative of all chemical elements, it rarely exists in elemental form. As the ground water passes through the fluoride rich rocks, it carries fluoride with it, hence most of the fluoride is found in ground water than surface water.

Excess intake of $\mathrm{F}$ results in fluorosis which is a chronic condition affecting both humans and animals and is endemic in many parts of the world including India (Khandare et al., 2005). In India, fluorosis is essentially hydrofluorosis and is endemic in parts of Punjab, Haryana, Rajasthan, Bihar, Madhya Pradesh, Orissa and 
Andhra Pradesh having high $F$ levels in underground water, soils and forages (Randhawa and Singh 2010). It is observed that fluorosis is most common in southwestern sub-region of Punjab, which covers Mansa, Bathinda, Muktsar and parts of Ferozpur districts. Ground water of these regions is highly saline and alkaline and livestock in these areas is highly susceptible to fluorosis.

The hazard for livestock may arise from excessive fluorine from mineral supplements, in contaminated forages by certain industrial processes, in drinking water, in feed concentrates. World Health Organization (1994) has set the upper limit of $F$ concentration in drinking water at $1.5 \mathrm{mg} / \mathrm{l}$ and the Bureau of Indian Standards (BIS), has therefore laid down Indian Standards as 1.0 $\mathrm{mg} / \mathrm{l}$ as maximum permissible limit of $\mathrm{F}$ with further remarks as "lesser the better" (Arlappa et al., 2013). Water $\mathrm{F}$ concentration above $1.5 \mathrm{ppm}$, have been reported to cause osteo and dental fluorosis in a wide range of domestic animals (Modasiya, 2014).

Calcification of certain ligaments rendering movement of joints difficult, is usually associated with at least $10 \mathrm{mg} / \mathrm{l}$ of fluoride in drinking water (Koli et al., 2017). According to (Sharma et al., 1995) fluoride content in drinking water of fluorotic areas ranges from over 1-9 ppm as compared to 0.4-0.8 ppm in non-fluorotic areas of Punjab.

Fluorine gets deposited in skeletal tissues and produce osteo-fluorotic lesions characterized by overt dental and bone lesions, lameness, deformed hooves, anemia, loss of body condition and emaciation. Higher intake of fluoride via ingestion or inhalation from a variety of sources is toxic to humans as well as animals leading to dental, skeletal and nonskeletal fluorosis (Shahab et al., 2017). The bone lesions are associated with excessive mobilization of Calcium (Ca) and Phosphorous (P) to compensate for their increased urinary excretion in conjunction with fluorine (Radostits et al., 2007). Being a strong electro-negative ion, $\mathrm{F}$ interacts with many other cations like Magnesium (Mg), copper $(\mathrm{Cu})$ and Zinc $(\mathrm{Zn})$ and affects their metabolism negatively. Diagnosis can be done by screening feed and water samples, blood as well as urine sample for F content.

\section{Materials and Methods}

The study was conducted in Mansa and Bathinda districts of South-western region of Punjab with the objective of identification of villages of Mansa and Bathinda districts where animals were consuming water with high $\mathrm{F}$ concentration. The drinking water was evaluated for the $F$ concentration in the $F$ endemic areas of Punjab.

The research work was carried out in the Department of Veterinary Medicine, Department of the Veterinary Public Health and Epidemiology in the College of Veterinary Science and Department of Aquaculture in the College of Fisheries Science, Guru Angad Dev Veterinary and Animal Sciences University, (GADVASU) Ludhiana, Punjab.

The epidemiological Survey was conducted in 7 villages of Mansa and 3 villages of Bathinda districts of Punjab. The total of 220 drinking water samples was collected from these villages for estimation of fluoride level in drinking water.

\section{Sample collection}

Approximately $200 \mathrm{ml}$ of drinking water meant for livestock was collected in the acid washed plastic bottles and stored at room temperature till further analysis and estimated for fluoride concentration, $\mathrm{pH}$ and alkalinity. 
Method of estimation for fluoride: Digital ion analyser along with Fluoride selective Electrode.

Method of estimation for $\mathrm{pH}$ : Professional multi parameter bench top $\mathrm{pH}$ meter (AD8000 laMotte, USA).

Method of estimation for alkalinity: Titration method.

\section{Statistical analysis}

The data was analysed by using SPSS (Statistical Package for Social Sciences) for Window version $16.0^{\circ}$ SPSS Inc. USA computer software program. The mean values of various parameters were calculated and presented along with respective standard errors and ranges. Correlation analysis was also calculated, using SPSS (Statistical Package for Social Sciences) for Window version $16.0^{\oplus}$ SPSS.

\section{Results and Discussion}

On the basis of survey, it was found that the ground water was the major source of drinking water for livestock in the form of tube well and hand pump water in villages of Mansa and Bathinda districts. In two villages namely, Sardulewala and Mussa in Mansa district, surface water in the form of tap water was used as an alternate source of drinking for livestock. Like many parts of the country, the tradition of animals having water from the village pond was not observed in the area of present studies.

\section{Fluoride (F) level in drinking water for livestock}

The overall range of $\mathrm{F}$ concentration in drinking water for livestock in Mansa and Bathinda were found to be $0.1-10$ and $0-10$ ppm respectively as presented in Table 1 and
2. The critical limit of $\mathrm{F}$ in drinking water is $1.5 \mathrm{ppm}$ for livestock. The mean concentration of $\mathrm{F}$ in the drinking water of village Gehle in district Mansa was $6.21 \pm 0.64$, with values ranging from 3-10 ppm. In this village $25.6 \%$ of the dairy animals manifest dental mottling whereas $51.6 \%$ of animals also showed skeletal fluorosis as well (Fig. 3). Similarly, in Bathinda district highest mean $\mathrm{F}$ in drinking water was found in Gheri village (4.1 \pm 0.45$)$, ranging from $0-10 \mathrm{ppm}$ and subsequently, maximum cases of dental mottling (52.6\%) and lameness (39.8\%) in livestock was found in this village (Fig. 1, 2 and 4). Similar observations of presence of hydroflurosis was reported by (Singh, 2012) in drinking water of Mansa, Bhikhi, Budhlada, Jhunir and Sardulgarh blocks in Mansa district.

Similarly, Sharma et al., (2014) revealed high $F$ level in drinking water of Faridkot and Bathinda districts of Punjab. Their findings suggest that these areas possess significantly higher levels of F in its water sources. Samel et al., (2016) suggested that deleterious effects due to chronic fluorosis are mostly irreversible.

The higher $\mathrm{F}$ concentration in the water can be of geogenic origin. The natural $\mathrm{F}$ in water is derived from solvent action of water on the rocks and soils of the earth's crust (Smith, 1983). Giri et al., (2013) revealed that the weathering and leaching process by percolating water in soil belts plays an important role in the occurrence of $\mathrm{F}$ in groundwater. Chatterjee et al., (2008) and Keesari et al.,(2007) suggested that high F in ground water may be due to leaching from fluoride-rich rocks present in the subsurface as well as due to anthropogenic activities. Several other workers (Beg et al., 2011 and Sharma et al., 2004) reported that high $\mathrm{F}$ levels in groundwater were largely governed by presence of $\mathrm{Ca}, \mathrm{Mg}, \mathrm{Na}, \mathrm{SiO}_{2}, \mathrm{PO}_{4}, \mathrm{pH}$ and alkalinity of the earth's crust. 
Table.1 Epidemiological survey of hydrofluorosis in livestock in district Mansa, Punjab

\begin{tabular}{|c|c|c|c|c|c|c|c|c|c|}
\hline \multirow{2}{*}{\multicolumn{2}{|c|}{ Name of the village }} & \multirow[t]{2}{*}{$\begin{array}{l}\text { Hydrofluorosis } \\
\text { (ppm) }\end{array}$} & \multicolumn{3}{|c|}{$\begin{array}{c}\text { Source of drinking water } \\
(\%)\end{array}$} & \multicolumn{4}{|c|}{ Clinical symptoms (\%) } \\
\hline & & & $\begin{array}{l}\text { Hand } \\
\text { pump }\end{array}$ & $\begin{array}{l}\text { Tube } \\
\text { well }\end{array}$ & $\begin{array}{c}\text { Tap } \\
\text { water }\end{array}$ & $\begin{array}{c}\text { Dental } \\
\text { mottling }\end{array}$ & Lameness & $\begin{array}{c}\text { lameness + } \\
\text { dental } \\
\text { mottling }\end{array}$ & Healthy \\
\hline \multirow{2}{*}{$\begin{array}{l}\text { Budhlada } \\
\qquad(\mathrm{N}=8)\end{array}$} & Mean \pm SE & $1.40 \pm 0.78$ & \multirow[t]{2}{*}{75} & \multirow[t]{2}{*}{23} & \multirow[t]{2}{*}{ - } & \multirow[t]{2}{*}{ - } & \multirow[t]{2}{*}{25} & \multirow[t]{2}{*}{-} & \multirow[t]{2}{*}{75} \\
\hline & Range & $0.10-5$ & & & & & & & \\
\hline \multirow[t]{2}{*}{ Ghele $(\mathrm{N}=14)$} & Mean \pm SE & $6.21 \pm 0.64$ & \multirow[t]{2}{*}{42.9} & \multirow[t]{2}{*}{57.1} & \multirow[t]{2}{*}{-} & \multirow[t]{2}{*}{19.2} & \multirow[t]{2}{*}{41.3} & \multirow[t]{2}{*}{16.7} & \multirow[t]{2}{*}{22.8} \\
\hline & Range & $3-10$ & & & & & & & \\
\hline \multirow{2}{*}{$\begin{array}{l}\text { Gagowal } \\
(\mathbf{N}=5)\end{array}$} & Mean \pm SE & $2.90 \pm 1.18$ & \multirow[t]{2}{*}{20} & \multirow[t]{2}{*}{80} & \multirow[t]{2}{*}{ - } & \multirow[t]{2}{*}{ - } & \multirow[t]{2}{*}{35.5} & \multirow[t]{2}{*}{-} & \multirow[t]{2}{*}{64.5} \\
\hline & Range & $0.5-7$ & & & & & & & \\
\hline \multirow{2}{*}{$\begin{array}{l}\text { Makha } \\
(\mathrm{N}=17)\end{array}$} & Mean \pm SE & $3.64 \pm 0.36$ & \multirow[t]{2}{*}{23.5} & \multirow[t]{2}{*}{76.5} & \multirow[t]{2}{*}{-} & \multirow[t]{2}{*}{26.5} & \multirow[t]{2}{*}{38.6} & \multirow[t]{2}{*}{8.7} & \multirow[t]{2}{*}{26.2} \\
\hline & Range & $2-6$ & & & & & & & \\
\hline Sardulewala & Mean \pm SE & $0.31 \pm 0.01$ & 68 & - & 32 & - & - & - & 100 \\
\hline & Range & $0.1-1.2$ & & & & & & & \\
\hline Mussa $(\mathbf{N}=3)$ & Mean \pm SE & $0.43 \pm 0.06$ & - & - & 100 & - & - & - & 100 \\
\hline & Range & $0.3-1.2$ & & & & & & & \\
\hline Sardulgarh & Mean \pm SE & $3.23 \pm 0.64$ & 23.07 & 76.9 & - & 4.5 & 14.3 & 19.1 & 62.1 \\
\hline & Range & $2-9$ & & & & & & & \\
\hline
\end{tabular}


Table.2 Epidemiological survey of hydrofluorosis in livestock in district Bathinda, Punjab

\begin{tabular}{|c|c|c|c|c|c|c|c|c|c|}
\hline \multirow{2}{*}{\multicolumn{2}{|c|}{ Name of the village }} & \multirow{3}{*}{$\begin{array}{c}\begin{array}{c}\text { Hydrofluorosis } \\
\text { (ppm) }\end{array} \\
1.36 \pm 0.35\end{array}$} & \multirow{2}{*}{\multicolumn{3}{|c|}{ Source of drinking water $(\%)$}} & \multicolumn{4}{|c|}{ Clinical symptoms (\%) } \\
\hline & & & & & & & & & \\
\hline \multirow{2}{*}{$\begin{array}{c}\text { Mehraj } \\
(\mathrm{N}=47)\end{array}$} & Mean +SE & & \multirow{2}{*}{42.6} & \multirow{2}{*}{57.4} & \multirow{2}{*}{-} & \multirow{2}{*}{-} & \multirow{2}{*}{17.1} & \multirow{2}{*}{-} & \multirow{2}{*}{82.9} \\
\hline & Range & $0-2$ & & & & & & & \\
\hline \multirow{2}{*}{$\begin{array}{c}\text { Kotshmair } \\
\quad(\mathbf{N}=\mathbf{3 0})\end{array}$} & Mean \pm SE & $0.54 \pm 0.05$ & \multirow[t]{2}{*}{26.7} & \multirow[t]{2}{*}{73.3} & \multirow[t]{2}{*}{ - } & \multirow[t]{2}{*}{$\begin{array}{l}- \\
-\end{array}$} & \multirow[t]{2}{*}{-} & \multirow[t]{2}{*}{-} & \multirow[t]{2}{*}{100} \\
\hline & Range & $0-1.5$ & & & & & & & \\
\hline \multirow{2}{*}{$\begin{array}{c}\text { Gheri } \\
(\mathbf{N}=33)\end{array}$} & Mean \pm SE & $4.1 \pm 0.45$ & \multirow[t]{2}{*}{30.3} & \multirow[t]{2}{*}{69.07} & \multirow[t]{2}{*}{ - } & \multirow[t]{2}{*}{44.2} & \multirow[t]{2}{*}{24.6} & \multirow[t]{2}{*}{23.6} & \multirow[t]{2}{*}{7.6} \\
\hline & Range & $0-10$ & & & & & & & \\
\hline
\end{tabular}

Table.3 Coefficient of correlation between Fluoride (F) with $\mathrm{pH}$ and alkalinity of drinking water

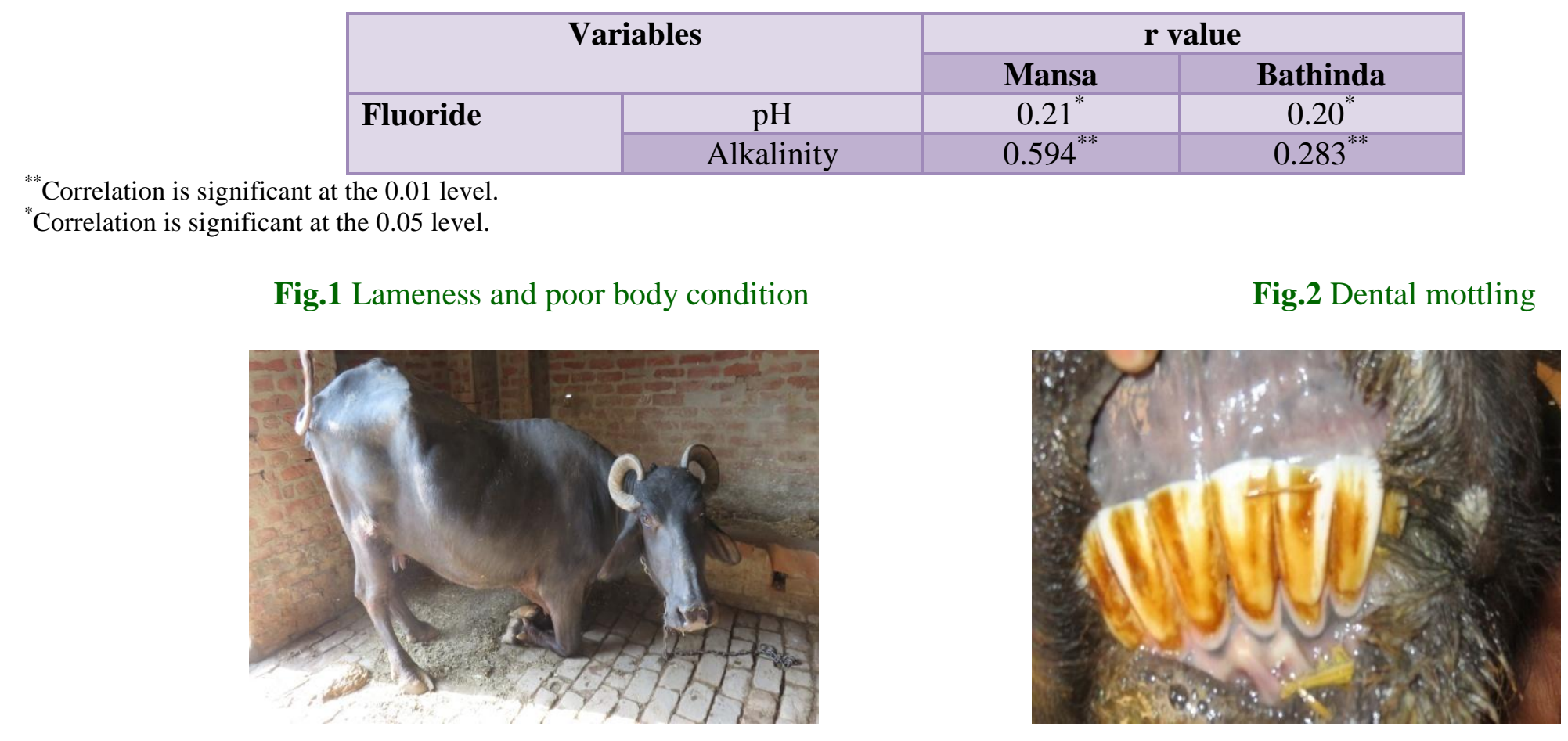


Int.J.Curr.Microbiol.App.Sci (2019) 8(8): 548-555

Fig.3 Clinical manifestation of livestock in district Mansa, Punjab

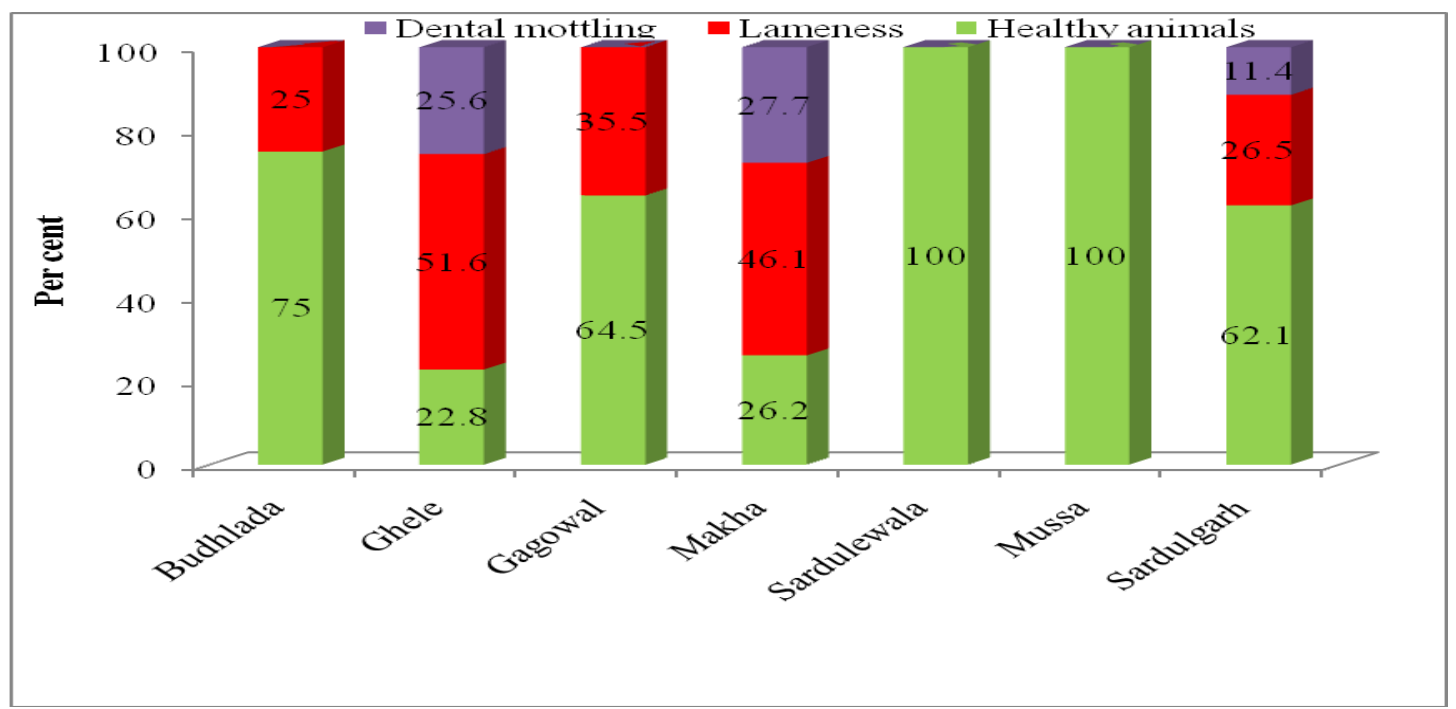

Fig.4 Clinical manifestation of livestock in district Bathinda, Punjab

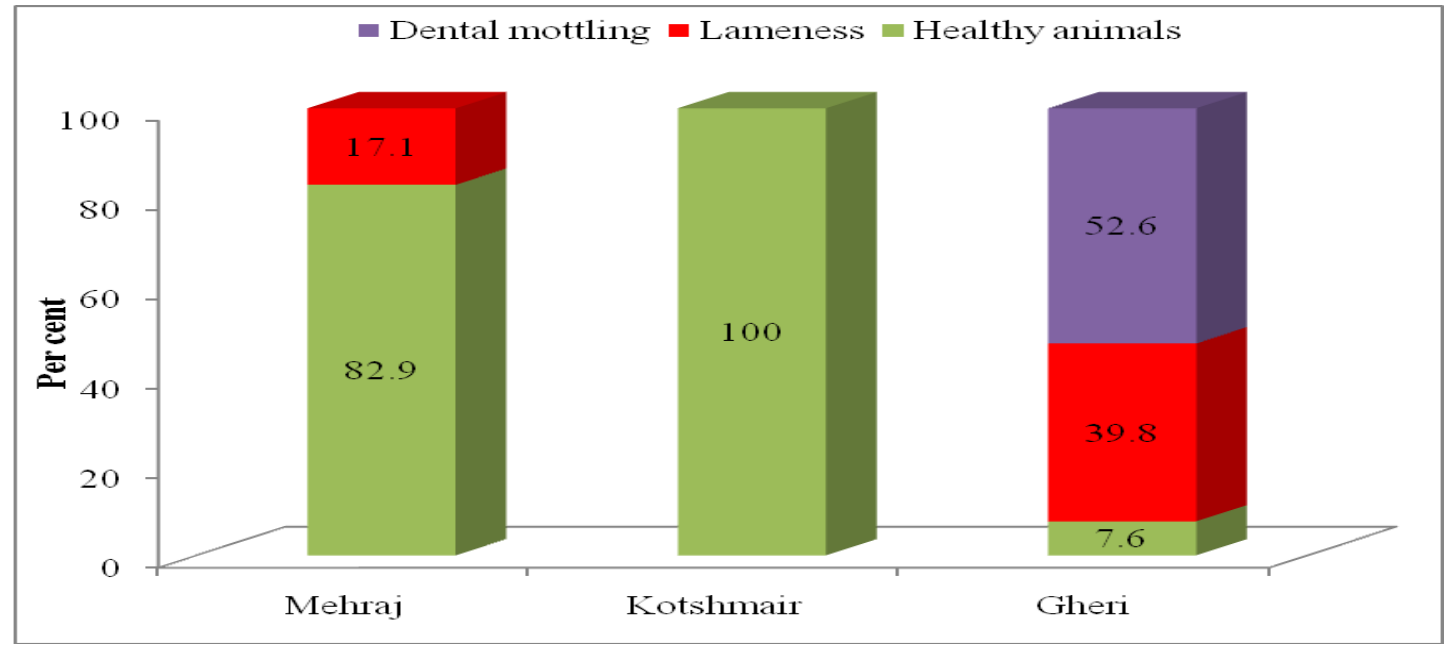


Positive correlation of $\mathrm{F}$ with $\mathrm{pH}$ and alkalinity in drinking water for livestock in Mansa and Bathinda districts, Punjab

In the present study it was found that there was a significant positive correlation of $\mathrm{F}$ with $\mathrm{pH}$ and alkalinity of drinking water in Mansa and Bathinda districts of Punjab (Table 3). Alagumuthu and Rajan (2008) has also observed a positive correlation between $\mathrm{F}$ and $\mathrm{pH}$ of ground water in Kadayam block of Tirunelveli district, Tamilnadu. Similarly, Nouri et al., (2006) reported the significant positive correlation between $\mathrm{F}$ content and alkalinity of groundwater in Iran. The positive correlation between alkalinity and F levels may be due to release of hydroxyl and bicarbonate ions simultaneously during the leaching and dissolution process of fluoride bearing minerals into water increases the $\mathrm{F}$ ion concentration with high levels of alkalinity as well. An alkaline environment of circulating water mainly facilitates leaching of $\mathrm{F}$ from the soils, contributing to high $\mathrm{F}$ containing groundwater (Rao and Devadas 2003). Fluorosis is the condition which is caused by intake of small but toxic amounts of fluoride in feed or drinking water over a long duration of time which is characterized by mottling of teeth and osteosclerosis of skeleton, lameness and is a serious health hazard for humans and animals. In India, fluorosis is endemic in many parts of various states including South-West Punjab where F content in the drinking water of the livestock in some areas is more than 6 times the permissible limits i.e $1.5 \mathrm{ppm}$. Thus, hydrofluorosis is a major problem in the ground water and is responsible for dental and skeletal fluorosis in the dairy animals.

\section{References}

Alagumuthu, G., and Rajan, M. 2008. Monitoring of fluoride concentration in ground water of Kadayam block of
Tirunelveli district, Tamilnadu India: correlation with physio-chemical parameters. Rasayan Journal of Chemistry. 1(4): 920-92.

Arlappa, N., Aatif Qureshi, I., and Srinivas, R. 2013. Fluorosis in India: an overview. International Journal of Research and Development of Health. 1(2): 97-102.

Beg, M. K., Srivastav, S. K., Carranza, E. J. M. and de Smeth, J. B. 2011. High fluoride incidence in groundwater and its potential health effects in parts of Raigarh district, Chhattisgarh, India. Current Science. 100(5): 750-54.

Chatterjee, A., Roy, R. K., Ghosh, U, C., Pramanik, T., Kabi, S. P. and Biswas, K. 2008. Fluoride in water in parts of Ranniganj Coalfield, West Bengal. Current Science. 94: 309-11.

Giri, D. K., Ghosh. R. C., Dey, S., Monda,1 M., Kashyap, D. K. and Dewanagan, G. 2013. Incidence of hydrofluorosis and its adverse effects on animal health in Durg district, Chhattisgarh. Current Science. 105(11): 1477-79.

Keesari, T., Shivanna, K., Jalihal, A. A. 2007. Isotope hyrrochemical approach to understand Fluoride release into groundwaters of Ilkal Area, Bagalkot District, Karnataka, India. Hydrogeology Journal. 15: 589-98.

Khandare, A. L., Harikumar, R. and Sivakumar, B. 2005. Severe bone deformities in young children from vitamin $\mathrm{D}$ deficiency and fluorosis in Bihar, India. Calcified Tissue International. 76: 412-18.

Koli, P., Yadav, S., Yadav, D. K. and Devi, S. 2017. Fluoride toxicity in livestock. Popular Kheti. 5(2):110-13

Modasiya, V., Bohra, D. L., Daiya, G. S. and Bahura, C. K. 2014. Observations of fluorosis in domestic animals of the Indian Thar Desert, Rajasthan, India. International Journal of Advanced 
Research. 2(4): 1137-43.

Nouri, J., Mahvi, A. H., Babaei, A. and Tehran, E. A. 2006. Regional pattern distribution of groundwater fluoride in the Shush aquifer of Khuzestan, Iran. Research Report Fluoride. 39(4):32125.

Radostits, O. M., Henchcliff, K. W., Gay, C. C. and Constable, P. D. 2007. Veterinary Medicine: A Textbook of the Diseases of Cattle, Horses, Sheep, Pigs and Goats. 10 ${ }^{\text {th }}$ Edn. W B Sounders Harcourt Publishers Ltd, London, pp. 1815-19.

Randhawa, S. S. and Singh, S. T. 2010. Mineral toxicities in dairy animals. Paper presented at National Symposium of ISVM on Recent Development in Diagnostic and Therapeutic Approaches for Economic Important Diseases of Livestock and Companion animals, held at Bombay Veterinary College, Mumbai from Feb. 17 to 19, India.

Rao, S. N. and John, D. 2003. Fluoride incidence in ground water in an area of Peninsular India. Environmental Geology. 45: 243.

Samal, P., Jena, D., Mahapatra, A., Sahoo, D., and Behera, S. 2016. Fluorosis: An epidemic hazard and its consequences on livestock population. Indian Farmer. 3(3): 180-184

Shahab, S., Mustafa, G., Khan, Imran., Zahid, M., Yasinzai, M., Ameer, N., Asghar, N., Ulla, H. I., Nadhman, A., Ahmed,
A., Munir,.I, Mujahid, A., Hussain, T., Ahmad, M. N. and Ahmad, S. S. 2017. Effeccts of Fluoride ion toxicity on animals, plants and soil health. Fluoride. 50(4) 393-408.

Sharma, C., Mahajan, A. and Garg, U. K. 2014. Fluoride and nitrate in groundwater of south-western Punjab, India - occurrence, distribution and statistical analysis. Desalination and Water Treatment. 57(9): 1-12.

Sharma, S. P., Randhawa, S. S. and Brar, R. S. 1995. Geomedical studies on fluorosis in dairy animals in Punjab, India. Ann Zootech. 44: 314.

Singh, S. T. 2012. 'Surveillance, clinicobiochemical and therapeutic studies on mineral imbalances in dairy animals of south-western region of Punjab.' Ph.D. dissertation. Guru Angad Dev Veterinary and Animal Sciences University, Ludhiana, India.

Smith, F. A. 1983. Overview of fluorosis in everyday life. In: Shupe J. L., Peterson, H. B. and Leone H C (Eds.) FluoridesEffects of vegetation, animals and humans. Paragon Press Inc., Salt Lake City, Utah, pp 7-20.

World Health Organisation. 1994. Expert committee on oral health status and fluoride use. Fluoride and oral health. WHO technical report series, 846. World Health Organisation, Geneva, pp 1-37.

\section{How to cite this article:}

Shikha Raina, Kirti Dua and Sikhtejinder Singh. 2019. Effect of Drinking Water Having High F Level on Livestock Health in Mansa and Bathinda Districts of Punjab, India. Int.J.Curr.Microbiol.App.Sci. 8(08): 548-555. doi: https://doi.org/10.20546/ijcmas.2019.808.065 